\title{
Techno-Economic Viability Test of Renewable Energy Supply Options in Developing Countries: Jordan Case Study
}

\author{
Mohammad A.A. Al-Jaafreh ${ }^{1}$, Geev Mokryani ${ }^{1}$ Abdalfettah Asharaa ${ }^{1,2}$, Okafor Ikenna \\ Anthony ${ }^{1,3}$, Rana Zubo ${ }^{1,4}$ Muhammad Baseer ${ }^{1}$ \\ \{M.A.A.Al-JaAfreh@bradford.ac.uk\} \\ ${ }^{1}$ University of Bradford, Bradford, West Yorkshire, United Kingdom, BD7 1DP \\ ${ }^{2}$ The Libyan Academy, School of Engineering and Applied Science, Libya, Tipoli \\ ${ }^{3}$ Federal College of Education (Technical) Umunze, Anambra State, Nigeria. \\ ${ }^{4}$ Northern Technical University,Technical College of Kirkuk,Iraq
}

\begin{abstract}
Jordan electricity demand is rapidly increasing and is expected to increase three times by 2030. Currently, deployment of renewable energy resource, especially solar and the wind is one of the considerable challenges of the government of Jordan. This research aims to investigate the status and prospect of renewable energy resource in Jordan. And, to test the potential renewable energy supply options in Jordan. A method for comparing the most viable energy supply options have been proposed and then applied into a technoeconomic feasibility case study to assess the viability of wind and solar energy resource in a particular area in the south of Jordan. HOMER software has been used to simulate and configure the system. The result showed that installing a PV solar farm has many advantages than installing a wind farm. The main benefits for the PV system are that it needs a lower installed capacity than wind system to meet the same load demand. Wind farm choice is less viable economically when it compared to the PV system; it needs higher capital and replacement cost. Also, the operating and maintenance cost of the wind farm much higher than that for the solar farm, (roughly up to ten times).
\end{abstract}

Keywords: Renewable Energy Resources (RERs), Techno-economic, Solar Photovoltaic (PV), Wind Turbine (WT), Homer Energy.

\section{Introduction}

Jordan is an emerging developing country in the Middle East. As opposed to most Middle Eastern countries, it has limited indigenous energy resource. Although the country produces crude oil and natural gas, the overall amounts do not exceed 3-4\% of total energy demand. Since Jordan imports $96 \%$ of the energy used, it is classified as non-oil producing country [1]. Also, electricity generation is heavily reliant on power plant operated by fossil fuel with $4416 \mathrm{MW}$ generation capacity in 2016[2]. On the other hand, due to the rapid rise in population, the average annual growth rate of electricity demand was 4.4\% from 2010 to 2016. In addition, it expected to increase by $6 \%$ for the period 2016-2030. Thus, the generation capacity needs to be extended to meet the future expected demand [3], [4]. Figure1 shows the projected electricity generation capacity that is required to meet demand by 2030 .

To improve the security of electricity supply and to resolve the electricity demand increasing problem, Jordanian government have started searching for the alternative source of energy [5]. Additionally, it should be providing a secure and reliable power generation, as well as it should support the government plan to stabilize the Green House Gas (GHG) [1]. The government master plan aims to overall develop the country energy sector to enable the best changes in market conditions. Also, it aims to increase reliance on local energy sources instead of dependence on imported fossil fuel [6]. Additionally, increase private sector investment in the development of the energy sector. In this context, the projected energy generation mix by 2020 
will be $29 \%$ natural gas, $14 \%$ from oil shelling, $6 \%$ from nuclear energy, and $10 \%$ of renewable energy, as shown in Figure 3 [7], [8].

The economic and technical challenges facing the Jordanian nuclear program and the antinuclear public pressure lead to suspending the program in 2018[3]. Also, oil shale continues to be riddled with uncertainty; the concentration has shifted to renewable energy [4]. While the combination of Jordan's geographical location and climate is expected to become one of the best renewable energy producers in the world. According to [9], Jordan will be able to shift to $100 \%$ Renewable energy generation. Jordan is located in Sunbelt location with direct solar radiation approximately available for 330 days/year within the solar intensity of $5-7(\mathrm{kWh} / \mathrm{m} 2$ d). Beside this solar energy supply, the country has several locations with average yearly wind speed in the range of 7-9 (m/s) at $50 \mathrm{~m}$ height above the ground [7], [9]

This paper assesses the status of renewable energy in Jordan. Related to this it present economic and technical assessment of wind and photovoltaic system in a selected location in Karak, Jordan to show most feasible potential renewable energy. The study considers both qualitative and quantitative assessment method. The system is modelled by using the Hybrid Optimization Model for Electric Renewable (HOMER). The rest of this paper is presented into five sections; the second section elaborates the current state of renewable energy in Jordan and provides two subsections to introduce the solar and wind energy resources in Jordan. Part three, introduce the simulation method while HOMER software will be used to design and assess the potential system. Section four elaborate data collection. Section five provides and discuss the result. Finally, section six concludes the work.

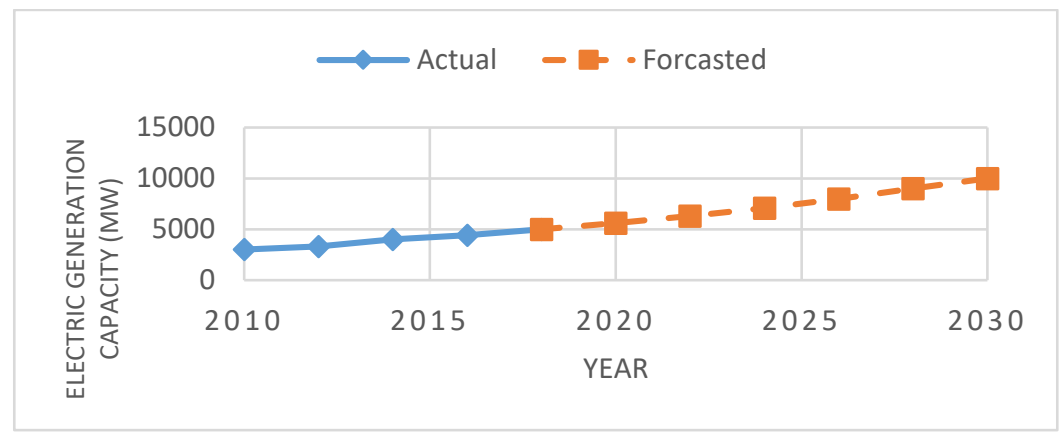

Fig 1. Actual and projected generation capacity (MW) by 2030 [1], [4]

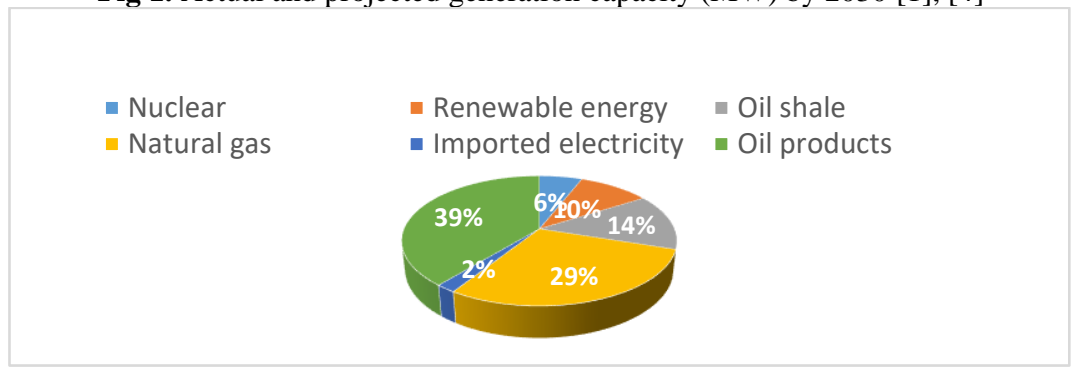

Fig 2. planned energy mix in Jordan by 2020 [7]

The main contribution of this work is:

1. Providing an insightful review of the status and prospects of the electricity system in Jordan, focusing on renewable energy penetration into the system. 
2. Proposed a method for comparing the most viable technologies available in the market for a specific site in the design stage, aims to minimise the total required capacity of the component and the total net present cost of the system

3. Carried out a techno-economic viability study of the electricity supply options, focussing in particular in a hypothetical case for a specific region of Jordan. The problem has been analysed carefully by designed a methodology to select the most viable energy supply solution and to conduct a case study applied to a grid-connected microgrid to supply the demand of 200 house in Karak city in southern Jordan.

\section{Renewable energy in Jordan}

Highlighted below is the current state of renewable energy resources in Jordan. While hydropower, biomass and geothermal energy are only available in a very limited area within the kingdom of Jordan [1], the study focused only on wind and solar.

\subsection{Solar energy}

2.1.1 Solar energy resource in Jordan

Jordan location is regarded as one of the sun-belt states, where most of its area is exposed to high solar radiation. The average solar radiation is in the range of $5-7\left(\mathrm{kWh} / \mathrm{m}^{2}\right)$ with an estimated 330 sunny day /year. In Addition, the country has an excellent climate with relatively moderate temperature and low humidity and dust level [1], [9]. Despite seasonal variation in the radiation intensity, this level of radiation is suitable for different solar applications such as photovoltaic cells (PV) and concentrated solar panel (CSP) [10]. Based on the distribution of the annual average of the daily global horizontal irradiation (GHI), Jordan can be divided into five regions as that shows in Figure 3 [1].

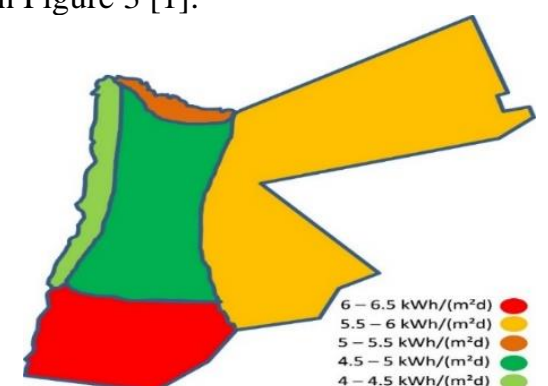

Fig 3. The regional annual average of daily Global Horizontal Irradiation (GHI) in Jordan [1]

\subsubsection{Status and prospect of solar energy in Jordan}

Presently there are approximately $15 \%$ of domestic buildings provide with the solar thermal system the government plans to increase the usage of the solar thermal system at the domestic building to $30 \%$ by 2020 [8]. Also, different large-scale PV solar systems projects have been implemented in key cities by the government, Table 1 provided the operated and planned solar PV projects that have been done or projected to work in future [2], [9].

Table 1: Governmental solar PV energy projects $[2,9]$

\begin{tabular}{|c|c|c|c|}
\hline \multirow{3}{*}{ Operated } & Project & Size (MW) & Year of operation \\
\cline { 2 - 4 } & Shams Maan & 53.1 & 2014 \\
\cline { 2 - 4 } & Al-Azraq & 5.17 & 2016 \\
\cline { 2 - 4 } & Al-Mafraq & 200 & 2016 \\
\cline { 2 - 4 } & Al-Quaira & 107 & 2017 \\
\hline \multirow{2}{*}{ Planned } & One new project & 200 & 2020 \\
\hline
\end{tabular}


Additionally, as a part of the government master plan, Energy regularity commission introduces a feed-in tariff of a renewable energy project. To encourage the private sector to invest in renewable energy by allowing them to export power to the electrical grid. Witch provides more certainty investment. Thus, let the private sector to play a part in improving the overall country energy sector [7],[8].

\subsection{Wind energy}

\subsubsection{Wind energy resource in Jordan}

Jordan has a considerable wind energy resource that can be exploited for power generation. The country wind atlas indicates the annual average wind speed at $50 \mathrm{~m}$ above the ground in a range of 3.5-8.5 (m/s). Figure 4 shows that Jordan can be characterised in five sectors in accordance with wind speed [1]. Also, there are selected places in the northern and western region with high potential wind speed [11].

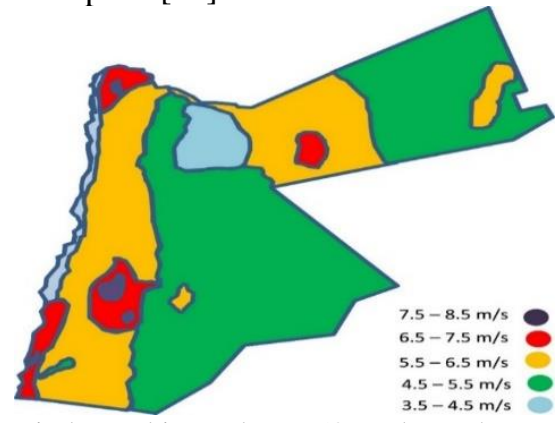

Fig 4. Wind speed in Jordan at $50 \mathrm{~m}$ above the ground [1]

\subsubsection{Status and prospect of Wind energy in Jordan}

Currently, wind generation capacity in Jordan is about 205 MW, delivered by two key electricity generation station, namely Jordan wind station, and Al-Hussain wind station. The government planned to launch new six projects with $420 \mathrm{MW}$ overall generation capacity; it is expected to be in operated by 2020[3]. Table 2 shows operated and planned government wind energy projects.

Table 1 Governmental Wind energy projects [3]

\begin{tabular}{|c|c|c|c|}
\hline & Project Name & Size (MW) & Year of operation \\
\hline \multirow{2}{*}{ Operated } & Jordan Wind & 117 & 2015 \\
\cline { 2 - 4 } & Al-Hussain & 88 & 2016 \\
\hline Planned & Six new projects & 420 & $2018-2020$ \\
\hline
\end{tabular}

\section{Methodology}

\subsection{Hybrid Optimization Model for Electric Renewable (HOMER)}

HOMER is primarily an optimization software package produced by national renewable energy laboratory for the US. The program assesses both technical and economic viability of renewable energy resource for a given configuration [12]. In other words, HOMER facilitates the optimisation of configuration based on a set of technical and economical set of constraint and sensitivity variable[13]. Also, HOMER is a time step simulator using hourly daily load and metrological data input to assess the renewable energy supply. Where the time step simulation 
method is the most common statistical used for renewable energy resource assessment [14]. Homer was chosen as primary application for this research as it is broadly used in previous renewable energy supply case studies such as [15],[13],[16],[12], [17],[18],[19],[14],[20] and [21].

\subsection{Technical assessment method used by HOMER}

The first stage of assessment is to estimate whether a system is technically feasible. Firstly, it calculates the energy supplied by a renewable resource, and it compared to required electricity load. If renewable energy supply satisfied the demand, the excess electricity generation is spread to other secondary demand, such as a storage system. If demand is not met, the alternative supplier is needed either diesel generator, a storage system or electricity grid to fill the defect [16].

3.2.1 Calculation method of PV array output

The output power of the PV array is calculated using the following equation [21],[22].

$$
P_{P V}=Y_{P V} f_{P V}\left(\frac{G_{T}}{G_{T, S T C}}\right)\left[1+\alpha_{P}\left(T_{C}-T_{C, S T C}\right)\right]
$$

Where $Y_{P V}$ is the rated capacity of PV array $(\mathrm{KW}), f_{P V}$ is the PV detreating factor, $G_{T}$ is solar radiation Incidence in the current time step $(\mathrm{kW} / \mathrm{m} 2), G_{T, S T C}$ is the incidence of solar radiation at standard test condition $\left(1 \mathrm{~kW} / \mathrm{m}^{2}\right)$ provided by the manufacturer., $\alpha_{P}$ the Temperature coefficient of power $\left(\% / C^{o}\right), T_{C}$ is $\mathrm{PV}$ cell tempter at the current time step, and $T_{C, S T C}$ is $\mathrm{PV}$ cell temperature under standard conditions $\left(25 C^{\circ}\right)$.

3.2.2 Calculation method of wind turbine output

Calculate wind speed at hub height:

If the anemometer and the hub are not at the same height. The software extrapolates the wind speed from anemometer height to hub height by using the following equation [21]

$$
U_{\text {hub }}=U_{\text {anem }} \frac{\operatorname{In}\left(Z_{\text {hub }} / Z_{o}\right)}{\operatorname{In}\left(Z_{\text {anem }} / Z_{o}\right)}
$$

Where $U_{h u b}$ is the wind speed at the hub height of the wind turbine $(\mathrm{m} / \mathrm{s}) U_{\text {anem }}$ is the wind speed at anemometer height $(\mathrm{m} / \mathrm{s}) Z_{h u b}$ : is the hub height of the wind turbine $(\mathrm{m}) Z_{\text {anem }}$ is the Anemometer height $(\mathrm{m}) Z_{o}$ is the Surface roughness length $(\mathrm{m})$.

Determine power output at standard pressure and temperature

After calculating the hub height wind speed, the wind turbine power curve can be used to determine the turbine output power. Figure 5 illustrates that the wind turbine provides no power if the hub height wind speed is not within the range defined in Power curve [22], [23].



Fig5. Wind turbine power curve [22]

Applying density correction factor: While the power curve specifies output power at standard temperature and pressure, the density correction factor is applied to adjust to actual condition, using the following expression [22] 


$$
P_{W T G}=P_{W T G, S T P} \cdot\left(\frac{\rho}{\rho_{O}}\right)
$$

Where: $P_{W T G}$ is wind turbine power output $(\mathrm{kW}), P_{W T G, S T P}$ is the wind turbine power output at standard conditions, $\rho$ is Actual air density $(\mathrm{kg} / \mathrm{m} 2), \rho_{O}$ is the air density at standard conditions $(1.255 \mathrm{~kg} / \mathrm{m} 3)$.

3.3 Economic assessment method used by HOMER

Net present cost (NPC) method used to represent the total life-cycle cost of the system. This includes all cost and revenue during the project lifetime with future cash flows discounted to the present. Costs include the initial cost of the system, cost of replacement and cost of maintenance. The NPC calculated by using the following equation [14]

$$
N P C=T A C \cdot\left[\frac{\left(1-(1+i)^{-N}\right.}{i}\right]
$$

Where: $N P C$ is the net present cost $(\mathbb{C}), T A C$ is the total annual cost $(\mathbb{C}), i$ is Annual effective interest rate (\%), and $\mathrm{N}$ is number of project years.

\section{Data collection}

\subsection{Site characteristic}

The selected location for the project is Karak city, Jordan. Karak city is situated $120 \mathrm{~km}$ south of capital Amman, the city located at high altitude region $858 \mathrm{~m}$ above the sea level, with coordinates $31^{\circ} 11^{\prime} 6 " \mathrm{~N}, 35^{\circ} 46^{\prime} 29^{\prime \prime} \mathrm{E}$ [24]. Figure 6 shows the location of the site. The study considers the area to supply 200 houses (domestic load) with electricity.

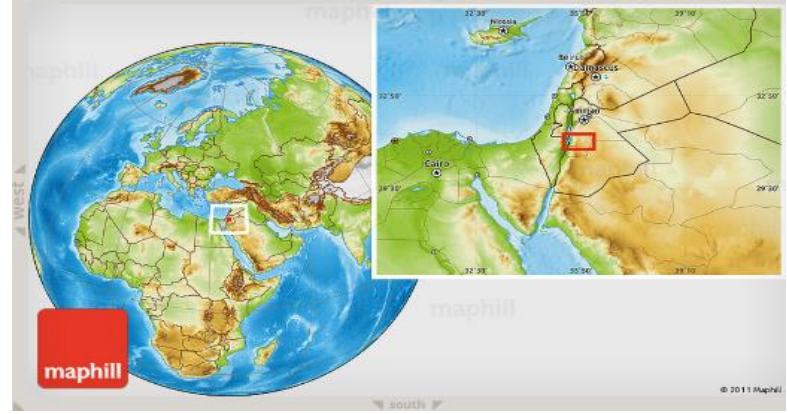

Fig 6. location of the project, Karak-Jordan [23]

\subsection{The load profiles}

The demand load data for 200 houses in the selected area, was secondary data obtained by [18] collected from the electric distribution company (EDCO). Which have details log for distribution substation power consumption. After analysing data using Excel software, Table 3 shows the average monthly load data.

Table 2.Average Monthly load (kW) (shown samples of hours)

\begin{tabular}{|c|c|c|c|c|c|c|c|c|c|c|c|c|}
\hline Time & Jan & Feb & Mar & Apr & May & Jun & Jul & Aug & Sep & Oct & Nov & Dec \\
\hline 00:00-1:00 & 44.3 & 32.1 & 35.3 & 33.4 & 43.4 & 45.9 & 43.0 & 50.5 & 45.4 & 38.3 & 31.2 & 44.9 \\
\hline $1: 00-2.00$ & 38.6 & 27.0 & 27.7 & 27.6 & 36.7 & 40.2 & 37.7 & 44.2 & 39.8 & 33.6 & 27.3 & 36.8 \\
\hline $2: 00-3: 00$ & 38.6 & 26.9 & 28.3 & 29.8 & 33.0 & 39.6 & 40.8 & 47.9 & 40.7 & 36.4 & 29.6 & 38.4 \\
\hline $3.00-4: 00$ & 38.6 & 27.7 & 27.5 & 30.8 & 34.1 & 40.1 & 42.1 & 49.4 & 41.0 & 37.5 & 30.5 & 36.7 \\
\hline $4: 00-5: 00$ & 132.8 & 95.3 & 94.4 & 105.9 & 117.1 & 138.0 & 144.8 & 169.9 & 147.7 & 129.0 & 104.9 & 126.2 \\
\hline
\end{tabular}




\begin{tabular}{|c|c|c|c|c|c|c|c|c|c|c|c|c|}
\hline 5:00-6:00 & 203.1 & 141.8 & 140.5 & 157.6 & 165.0 & 205.3 & 208.2 & 252.8 & 189.0 & 191.9 & 156.1 & 187.8 \\
\hline $6: 00-7: 00$ & 223.4 & 158.3 & 150.0 & 168.3 & 174.6 & 207.5 & 207.1 & 247.2 & 195.3 & 208.0 & 166.6 & 224.6 \\
\hline 7:00-8:00 & 203.1 & 171.0 & 150.7 & 182.3 & 187.1 & 197.8 & 201.1 & 233.8 & 203.9 & 224.1 & 160.6 & 239.3 \\
\hline 8:00-9:00 & 170.6 & 161.2 & 134.5 & 151.8 & 149.9 & 198.7 & 189.0 & 187.1 & 185.0 & 194.1 & 145.3 & 229.2 \\
\hline 9:00-10:00 & 174.7 & 166.7 & 137.1 & 155.6 & 141.5 & 165.7 & 180.0 & 82.6 & 197.5 & 170.6 & 152.1 & 27.9 \\
\hline 10:00-11:00 & 201.1 & 182.3 & 160.2 & 157.3 & 195.0 & 181.9 & 228.2 & 212.2 & 225.7 & 193.2 & 63.0 & 238.7 \\
\hline 11:00-12:00 & 216.5 & 207.1 & 173.9 & 188.9 & 215.7 & 209.5 & 260.7 & 257.4 & 252.7 & 211.9 & 76.9 & 273.7 \\
\hline $12: 00-13: 00$ & 280.7 & 341.4 & 260.9 & 291.1 & 328.5 & 334.0 & 347.0 & 342.0 & 368.4 & 294.4 & 267.1 & 382.2 \\
\hline 13:00-14:00 & 210.8 & 241.6 & 230.5 & 195.7 & 235.0 & 262.9 & 254.9 & 261.4 & 243.8 & 238.3 & 231.1 & 282.5 \\
\hline $14: 00-15: 00$ & 169.8 & 199.0 & 203.0 & 157.5 & 191.9 & 168.1 & 205.0 & 220.7 & 181.9 & 177.6 & 161.3 & 198.9 \\
\hline 15:00-16:00 & 161.3 & 176.9 & 171.3 & 136.4 & 167.5 & 156.5 & 185.3 & 167.6 & 178.1 & 165.1 & 160.6 & 168.5 \\
\hline $16: 00-17: 00$ & 166.1 & & & & & & & & 85.0 & 171.4 & 6.5 & 181.5 \\
\hline 17:00-18:00 & 267.3 & 301.1 & 260.2 & 250.7 & 235.2 & 273.8 & 284.5 & 288.3 & 257.7 & 239.2 & 264.6 & 257.7 \\
\hline 18:00-19:00 & 500.0 & 500.0 & 500.0 & 500.0 & 500.0 & 500.0 & 500.0 & 500.0 & 500.0 & 500.0 & 500.0 & 500.0 \\
\hline 19:00-20:00 & 407.4 & 428.3 & 463.6 & 422.6 & 460.1 & 428.3 & 409.8 & 435.0 & 428.3 & 443.7 & 428.3 & 469.9 \\
\hline $20: 00-21: 00$ & 274.6 & 278.3 & 301.3 & 256.4 & 312.8 & 290.6 & 266.4 & 344.6 & 278.3 & 288.4 & 278.3 & 325.9 \\
\hline $21: 00-22: 00$ & 195.0 & 193.2 & 206.0 & 175.4 & 193.2 & 210.2 & 184.9 & 227.5 & 193.2 & 197.0 & 181.2 & 212.2 \\
\hline $22: 00-23: 00$ & 121.9 & 109.2 & 128.0 & 94.7 & 114.4 & 125.1 & 118.4 & 137.3 & 123.8 & 116.0 & 104.4 & 128.3 \\
\hline 23:00-0:00 & 82.9 & 81.2 & 83.8 & 66.5 & 87.9 & 91.4 & 83.8 & 118.1 & 91.4 & 90.4 & 78.3 & 92.1 \\
\hline
\end{tabular}

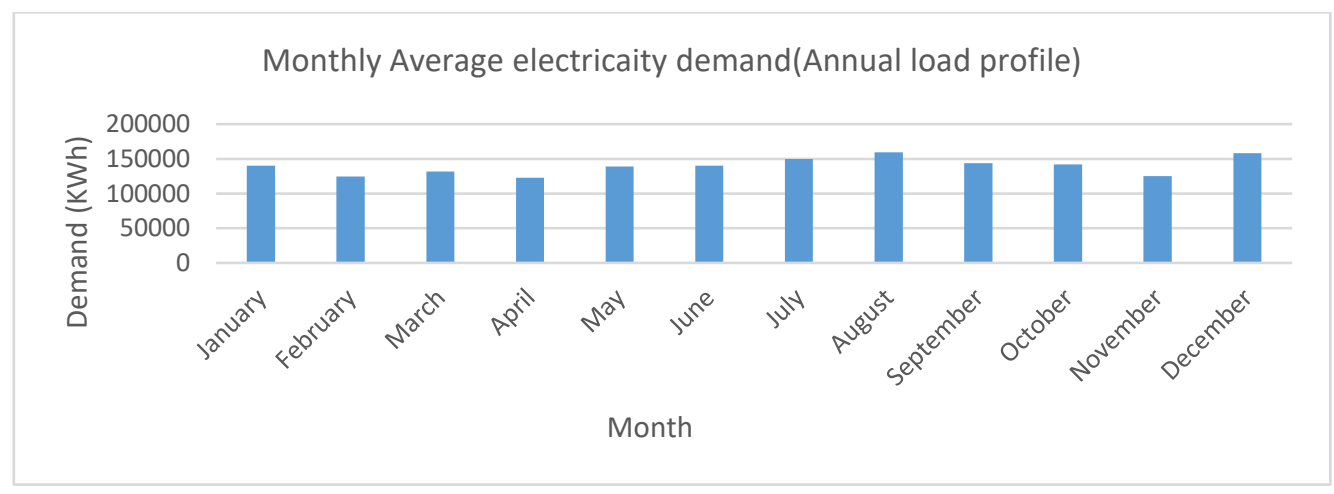

Fig7. Annual load profile

The annual load profile in Figure 7 shows that Annual energy needs are 1625710 MWh with its peak load demand being $492 \mathrm{KW}$ during the year, and the average energy consumption per day is $4495 \mathrm{KWh}$.

\subsection{Metrological data}

4.3.1 solar irradiation

The record data for solar irradiance is acquired using HOMER, which gets this data from the Database of NASA. The scaled annual average of solar global horizontal irradiance (GHI) found to be $5.15(\mathrm{kWh} / \mathrm{m} 2 /$ day $)$. Figure 8 and Table show the monthly average solar GHI data at Karak, Jordan [22]. 


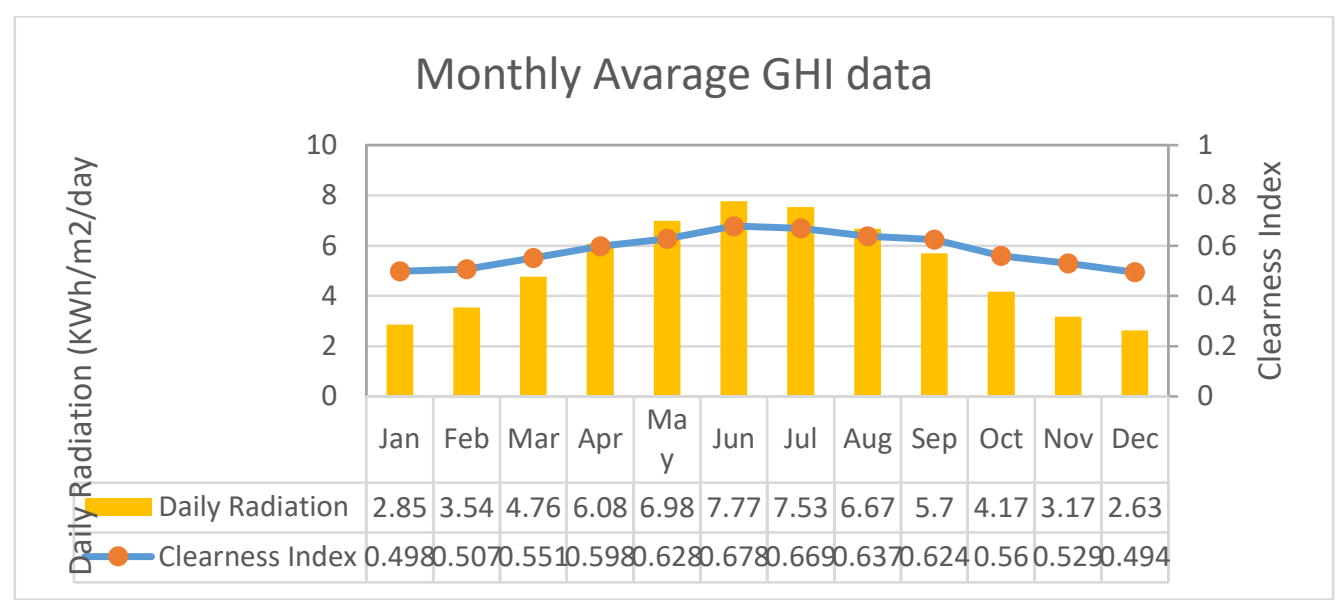

\subsubsection{Wind speed}

Fig 8. Monthly average solar GHI at Karak, Jordan [22]

The wind speed for the selected location is found using HOMER software, which got this data from NASA surface meteorology and solar energy database. The monthly average wind speed $(\mathrm{m} / \mathrm{s})$ are shown in Figure 9 and Table. And the Annual Average wind speed was found as $5.22(\mathrm{~m} / \mathrm{s})[22]$.

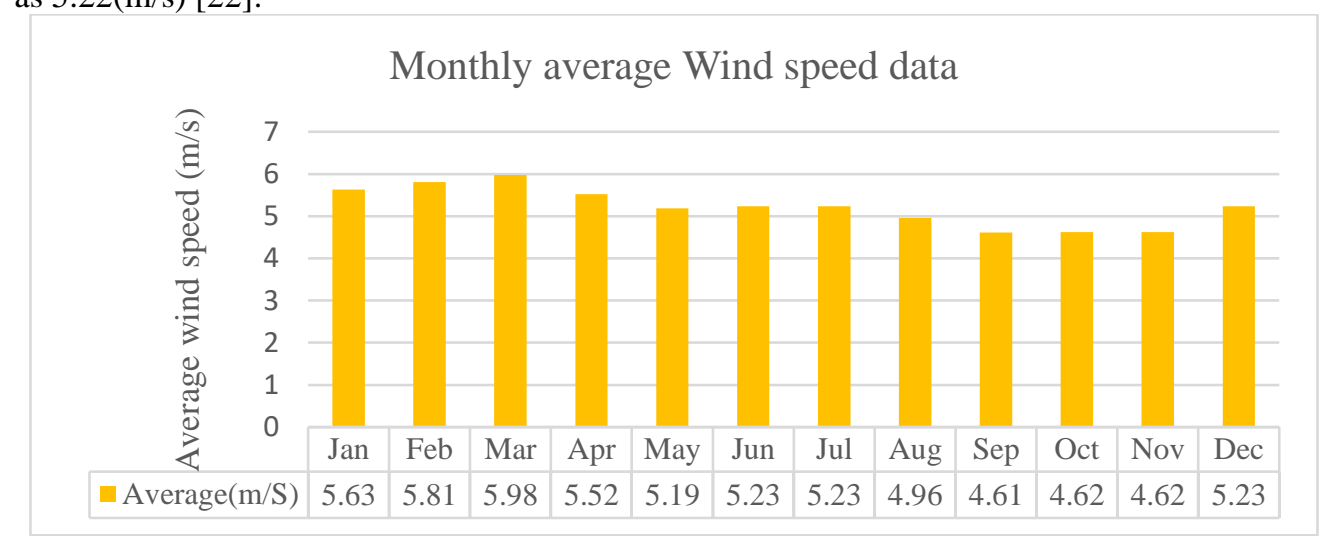

\section{Technology selection}

Fig 9. Monthly average wind speed at Karak-Jordan [22]

Although hydropower, Biomass energy, and geothermal energy are available in Jordan, they are only available on the minimal area within the country. Therefore, the viability test and the selection of technology will be focused on PV solar panel and wind turbine.

\subsection{Wind Turbine Selection}

There are plenty of wind turbines available in the market. Different characteristic for different applications. To select the best wind turbine, the average wind speed available during the year must be considered, and the size of the system [25]. In this case study, the system recognises as medium size with $500 \mathrm{~kW}$ peak load demand and1.68 (GWh) total annual energy requirement. The yearly average wind speed is $5.22(\mathrm{~m} / \mathrm{s})$. Because of the very low efficiency of the vertical wind turbine, the horizontal wind turbine is only considered in selection [26]. 
The large wind turbines are excluded because the large unit is non-feasible and inefficient for the medium system as well as unreliable. In addition, the average wind speed in the selected side was $5.22(\mathrm{~m} / \mathrm{s})$ while the cut-in speed for a vesta wind turbine as an example $4(\mathrm{~m} / \mathrm{s})$. Also, it is inefficient, since it has less than $15 \%$ efficiency at the selected location. While energy production at $5.22(\mathrm{~m} / \mathrm{s})$ average wind speed is $1300 \mathrm{MWh}$, this is deficient based on the rated capacity of the turbine $(660 \mathrm{KW})$. The main features of a Vestas-100c-24 wind turbine are shown in Table4. Moreover, the small size wind turbine is excluded because the number of turbines needs to be used very large as well as the area [27]. Also, the overall system will not be reliable [28].

After excluding the small and large size wind turbine, three $100(\mathrm{~kW})$ rated capacity wind turbine has been selected. Table4 shows the main properties of those wind turbines. Figure 11c shows that at the annual average wind speed for selected location $5.22(\mathrm{~m} / \mathrm{s})$, NPS-100C -24 wind turbine roughly produce $250 \mathrm{MWh} /$ year. However, Norvento (nED100) and XANT M21-ETR wind turbines produce only 200(MWh/year) as that shown in Figure 11-b, d. Also, the rated wind speed for NPS-100C -24 turbine is lower than that for Norvento (nED100) and XANT M-21-ETR as that shown in Table 5. Therefore, the NPS-100C -24 wind turbine has been selected to use in the system configuration. Table 4 conclude the costs considered for the selected wind turbine.

Table 3.NPS-100C -24 cost summery

\begin{tabular}{|c|c|}
\hline Type & NPS-100C -24 \\
\hline Capital cost (£) & 100,000 \\
\hline Replacement cost (£) & 70,000 \\
\hline O\&M(£/year) & 5000 \\
\hline
\end{tabular}

Table 4.Main properties of different wind turbines[26],[28] and [29]

\begin{tabular}{|c|c|c|c|c|}
\hline Type & Vestas-100c-24 & Norvento(nED100) & NPS-100C -24 & XANT M-21-ETR \\
\hline Hub Height (m) & 50 & 36 & 29 & 38 \\
\hline $\begin{array}{l}\text { Rated } \\
\text { capacity }(\mathrm{kW})\end{array}$ & 660 & 100 & 100 & 100 \\
\hline Rotor diameter(m) & $47 \mathrm{~m}$ & 22 & 24.4 & 21 \\
\hline Rotor axis & Horizontal & Horizontal & Horizontal & Horizontal \\
\hline Lifetime (Year) & 20 & 20 & 20 & 20 \\
\hline Power curve & Figure10, a & Figure $10, \mathrm{~b}$ & Figure $10, \mathrm{c}$ & Figure 10, d \\
\hline $\begin{array}{l}\text { Annual energy } \\
\text { production } \\
\text { (MWh/year) }\end{array}$ & Figure11, a & Figure11, b & Fig 11, c & Figure 11, d \\
\hline Description & $\begin{array}{l}\text { The cut in speed } 4 \mathrm{~m} / \mathrm{s} \\
\text { and the max generation } \\
\text { at } 16 \mathrm{~m} / \mathrm{s} \text {, mostly used } \\
\text { for large-scale (Utility- } \\
\text { scale system) }\end{array}$ & $\begin{array}{l}\text { Design for max ero- } \\
\text { dynamic capture } \\
\text { mechanical and } \\
\text { electrical with cut-in } \\
\text { speed } 3 \quad(\mathrm{~m} / \mathrm{s}) \text { and } \\
\text { provide } \quad \max \\
\text { generation at } 10(\mathrm{~m} / \mathrm{s})\end{array}$ & $\begin{array}{l}\text { The best feature is } \\
\text { that turbine } \\
\text { optimized for low } \\
\text { wind regimes, with } \\
\text { average annual below } \\
7.52(\mathrm{~m} / \mathrm{s}) \text { cut in } \\
\text { speed is } 3(\mathrm{~m} / \mathrm{s}) \text { and } \\
\text { provide max gen at } \\
12(\mathrm{~m} / \mathrm{s})\end{array}$ & $\begin{array}{l}\text { Design to capture low } \\
\text { wind speed with } 3 \\
(\mathrm{~m} / \mathrm{s}) \text { cut in speed and } \\
\text { provide } \max \\
\text { generation at } 11(\mathrm{~m} / \mathrm{s})\end{array}$ \\
\hline
\end{tabular}




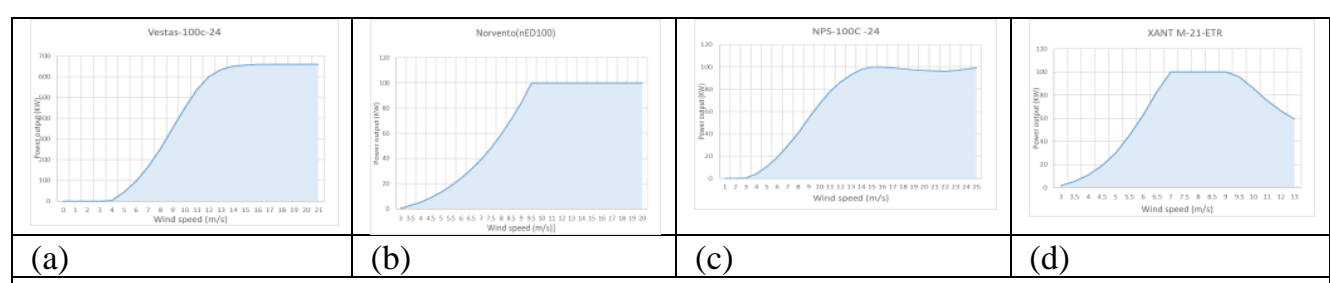

Fig 10. Power curve for different wind turbine at hub Hight wind speed [26], [28], [29] and [30]

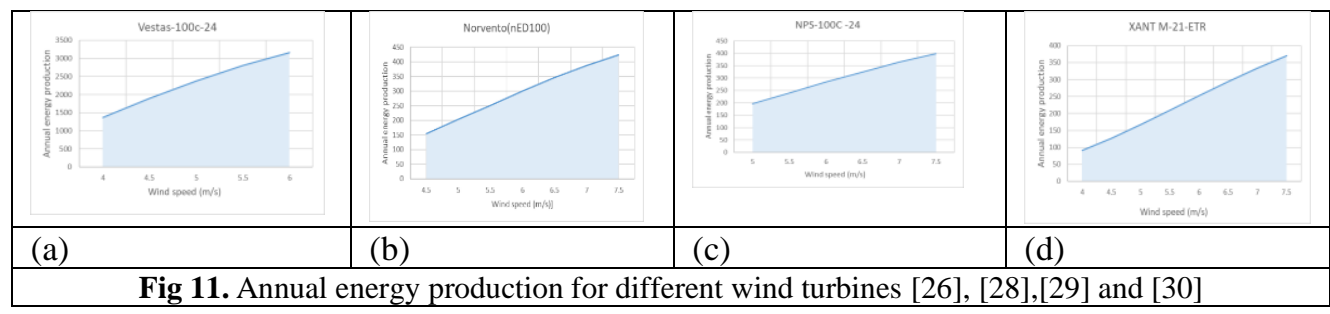

\subsection{PV array selection}

To select the optimal PV panel, many variables should be considered, such as conversion efficiency, space efficiency (Area/KW) and cost. PV cell type is selected based on the material and solar model. In terms of material, the main types are crystalline silicon(C-Si) and Thin-film PV panel. C-Si is the most widely used and available in the market. On the other hand, Thin film PV panel (such as Amorphous and copper indium gallium selenide CIGS) have low conversion efficiency and low space efficiency when compared to C-Si Panels [31]. Therefore, it is considered as an inconvenient choice for the selected location. Table 6 shows the main properties, Pros and cons for the thin-film PV array.

Table 5. Main properties, advantages and disadvantages for thin-film PV array [32].

\begin{tabular}{|c|c|c|c|}
\hline Properties & & Advantages & Disadvantages \\
\hline Conversion efficiency & $7-13 \%$ & \multirow{5}{*}{$\begin{array}{l}\text { Simple and cheaper to } \\
\text { manufacture than C- } \\
\text { Si. } \\
\text { Less impact of panel } \\
\text { performance at high } \\
\text { temperature. }\end{array}$} & \multirow{5}{*}{$\begin{array}{l}\text { Required massive spec (low } \\
\text { space efficiency). } \\
\text { Lower lifespan; tend to } \\
\text { degrade faster than C-Si solar } \\
\text { panels. }\end{array}$} \\
\hline Area required $\left(\boldsymbol{m}^{2} / \mathrm{kW}\right)$ & $13-20 \mathrm{~m}$ & & \\
\hline Lifespan(years) & $10-20$ & & \\
\hline Lowest price (£/kW) & 690 & & \\
\hline Temp resistance & $\begin{array}{l}\text { Tolerates extreme } \\
\text { temp }\end{array}$ & & \\
\hline
\end{tabular}

Based on the purity of silicon, crystalline silicon PV panel divided into monocrystalline silicon solar panel (Mono-Si) and polycrystalline silicon solar panel (P-Si). Mono-Si indicates high purity silicon which is made of silicon ingot that cylindrical. The efficiency of the solar panel goes in parallel with the purity of silicon, but the costly complicated process needs to enhance the purity of the silicon. However, in P-Si manufacturing, raw silicon is melted and purred into the square model that is cooled and cut in into the square wafer. Table7, illustrate the main properties and pros, and cons of Mono-Si and P-Si solar panels [33],[31].

Table 6. Main properties, Advantages and disadvantages of Mono-Si and P-Si solar panel [33]

\begin{tabular}{|l|l|c|}
\hline Type & Mono-Si & P-Si \\
\hline Properties & & \\
\hline
\end{tabular}




\begin{tabular}{|c|c|c|}
\hline Conversion efficiency & $15-20 \%$ & $13-16 \%$ \\
\hline $\begin{array}{ll}\text { Area } & \text { required } \\
\left(\mathrm{m}^{2} / \mathrm{kWm} / \mathrm{kW}\right) & \end{array}$ & $5-9$ & $8-9$ \\
\hline Lifespan(years) & 25 & 25 \\
\hline Lowest price $(£ / \mathrm{kW})$ & 750 & 620 \\
\hline Temp resistance & $\begin{array}{l}\text { Efficiency drop to } 10-15 \% \text { at high } \\
\text { temperature }\end{array}$ & Lower heat tolerance than Mono-Si \\
\hline Advantages & $\begin{array}{l}\text { Made of highest-grade silicon and } \\
\text { have the highest efficiency rate. } \\
\text { The most space-efficient, which } \\
\text { required the least area compared to } \\
\text { other types (for the same panel area } \\
\text { produce four times of electricity as a } \\
\text { thin-film panel. } \\
\text { Long lifespan, roughly } 25 \text { years } \\
\text { Better performance than similarly } \\
\text { rated P-Si at the low light level. }\end{array}$ & $\begin{array}{l}\text { The manufacturing process is simpler and } \\
\text { less expensive and lowers Silicon waste } \\
\text { compared to Mono-Si. } \\
\text { Less expensive than Mono-Si }\end{array}$ \\
\hline Disadvantages & $\begin{array}{l}\text { Most expensive solar panel } \\
\text { If the panel is partially covered with } \\
\text { shade, snow, dirty, the entire circuit } \\
\text { could be broken down. } \\
\text { Tend to be less efficient at high } \\
\text { temperature }\end{array}$ & $\begin{array}{l}\text { Less efficient than Mono-Si because of } \\
\text { lower silicon Purity. } \\
\text { Low space-efficiency compared with } \\
\text { Mono-Si. } \\
\text { Perform slightly worse than Mono-Si at } \\
\text { high temperature. }\end{array}$ \\
\hline
\end{tabular}

Monocrystalline solar panels are generally utilised for large-scale solar applications, either for residential or commercial solar installation [31]. Also, the above discussion illustrates that Monocrystalline solar panel is the most efficient technology available in the market. While the area available to install the system in the selected location is a concern, the Mono-Si solar panel will be the best choice. Although the overall project price will be high, the long lifespan and high-temperature tolerance of Mono-Si can reduce the cost of maintenance along with the project life. As a result, Monocrystalline silicon (X21-335-BLK) flat PV Panel, which is the latest version SunPower company with the highest efficiency compared to other $21 \%$ selected to use in the system. Table 8 shows the main properties of the solar panel.

Table 7. PV array properties and costs,[22], [33]

\begin{tabular}{|l|l|}
\hline Parameter & Value \\
\hline Type & SunPower X21-335-BLK \\
\hline Material & Mono-Si \\
\hline Rated capacity $(\mathrm{kW})$ & 0.335 \\
\hline Area required $\left(\boldsymbol{m}^{2} / \mathrm{kW}\right)$ & 5 \\
\hline Lifespan $($ year $)$ & 25 \\
\hline price $(\mathfrak{f} / \mathrm{kW})$ & 1500 \\
\hline Temperature coefficient $\left(\boldsymbol{\%} / \boldsymbol{C}^{o}\right)$ & -0.3 \\
\hline Detreating Factor & $88 \%$ \\
\hline Slope & 30.7667 \\
\hline Azimuth & 0 \\
\hline Ground reflectance & $20 \%$ \\
\hline Tracking system & No tracking \\
\hline
\end{tabular}




\subsection{Electricity grid}

To test the viability of wind and solar renewable resource, the cost of electrical energy purchase to the network and the back sell price consider being the same. This price set to be 0.1 $(\mathfrak{f} / \mathrm{kWh})$.

\section{System Configurations}

To compare solar and wind renewable energy resources, two grid-connected system configurations is modelled using HOMER. Both configurations have the same electric load with average daily electricity consumption $4595(\mathrm{kWh} /$ day $)$ and the same price for purchase and sell back from and to the grid. The project life has assumed to be 25 years with $6 \%$ /year effective interest rate. Figure 12(a and $b$ ) shows the system configurations.

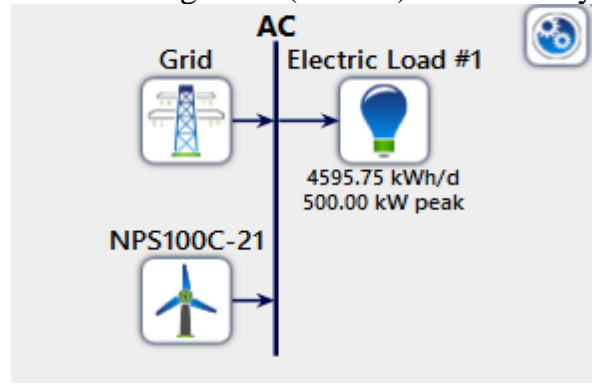

(a) Grid-Connected Wind system

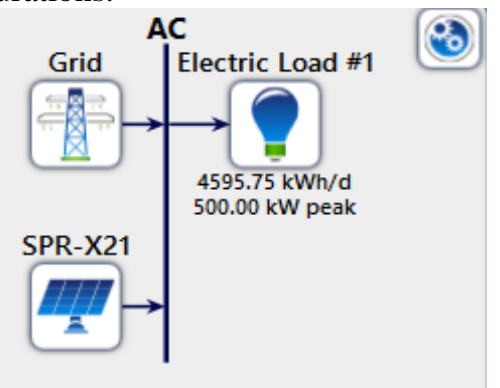

(b)Grid-Connected PV system

Fig 12. The grid-connected $P V$ and wind systems

\section{Simulation Results and Discussion}

\subsection{First scenario: grid-connected wind system}

After performing a simulation of the system model, Table 9 summarises the capacity considered, and the area needed to install the system. It also shows that wind farm supplies 80.8 $\%$ of load.

Table 8. Main parameters of the connection to the grid wind system

\begin{tabular}{|c|c|l|l|l|c|}
\hline First Scenario & \multicolumn{3}{|c|}{ Wind Turbines } & \multicolumn{1}{|c|}{$\begin{array}{c}\text { Electricity } \\
\text { grid }\end{array}$} & $\begin{array}{c}\text { System } \\
\text { Renewable } \\
\text { fraction }\end{array}$ \\
\hline falue & $\begin{array}{c}\text { Capacity } \\
\text { considered } \\
(\mathrm{kW})\end{array}$ & $\begin{array}{l}\text { Number of } \\
\text { Turbines }\end{array}$ & $\begin{array}{l}\text { Wind } \\
\text { Farm Area } \\
\left(\mathrm{km}^{2}\right)\end{array}$ & $\begin{array}{l}\text { Available to } \\
\text { purchase and } \\
\text { sail } \\
\text { electricity as } \\
\text { needed }\end{array}$ & $80.8 \%$ \\
\hline Valuen & 2000 & 20 & 2.4 & \\
\hline
\end{tabular}

The equation used to calculate the area need to installed wind farm illustrated following [1]:

$$
\text { Area }=\sqrt{\frac{3}{4}} \times\left(K \times D_{\text {rotor }}\right)^{2} \times N
$$

Where $K$ is the distance factor, the minimum distance between two turbines (Typically 10 $15 \mathrm{~m}), D_{\text {rotor }}$ are the wind turbine rotor diameter and $N$ is the number of wind turbines Electricity production and consumption

Table10 summarises the annual electricity consumption and production. It shows that the Annual electricity consumption is $1.68 \mathrm{MWh}$. While the wind farm produces $80.8 \%$ of 
electricity, only $19.2 \%$ purchased from the grid. Also, $52 \%$ of generation is sold to the network, and that happens when the wind farm supply higher than the Load. Figure13, illustrate the monthly average electricity production it shows that the highest wind farm production occurs in March.

Table 9. first scenario annual electricity production and consumption

\begin{tabular}{|l|c|c|}
\hline \multicolumn{2}{|c|}{ Production } \\
\hline Component & GWh/Year & $\%$ \\
\hline Wind Farm & 2.83 & $80.8 \%$ \\
\hline Grid purchase & 0.67 & $19.2 \%$ \\
\hline Total & 3.5 & $100 \%$ \\
\hline & Consumption & \\
\hline & GWh/year & $48 \%$ \\
\hline Ac -Load & 1.68 & $52 \%$ \\
\hline Grid sales & 1.82 & $100 \%$ \\
\hline Total & 3.50 & \\
\hline
\end{tabular}

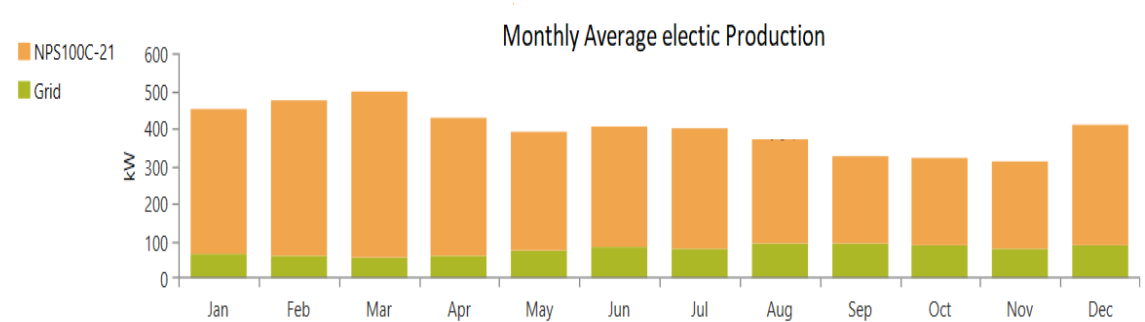

Fig 13. Grid-connected wind monthly average electric production

Table 10.Wind farm cost summary

\begin{tabular}{|c|c|c|c|c|c|}
\hline $\begin{array}{c}\text { Wind Farm } \\
\text { consists of } 20\end{array}$ & Capital & Replacement & O\&M & Salvage & Total \\
$\begin{array}{c}\text { (NPS-100C -24) } \\
\text { wind turbines }\end{array}$ & $£ 2.00 \mathrm{M}$ & $£ 0.44 \mathrm{M}$ & $£ 1.30 \mathrm{M}$ & $-£ 0.25 \mathrm{M}$ & $£ 3.49 \mathrm{M}$ \\
\hline
\end{tabular}

Overall, the analysis shows that both systems are technically feasible to meet the demand. However, there are many differences between the systems, which make one of them is more viable for the selected location. Regarding area available for installing the system, the wind farms us the most feasible one, which needs three times lower land than that for the solar system. Also, the area under the system can be used for other purposes in contrast with the PV system. Although the area needed for the solar system is much higher than that for wind, the advantages for a solar farm is much more than for wind farm, firstly the solar going to be useful to meet the load demand and less installed capacity is needed. While wind farm maintenance and operating cost are very high, the cost of maintaining the solar farm is much lower. Also, the total cost of the solar system is roughly half of the total cost of the wind system, which means the PV solar farm choice is more economically feasible. Finally, a solar option is much beneficial than the wind farm, even though the solar system needs more area to be installed.

Hybrid system is defined as a system with two types of generation resource. In this case, study of hybrid system consists of PV solar and Wind. This have various advantages, which is considered as an excellent choice to combine the benefits of PV system and the advantages of 
wind system, also, resolve the problem that occurs when using only one technology. Firstly, the overall area of the Hybrid system will be much less than that needed for PV farm. Also, technically the system will be more reliable while it has PV and wind; the system will be able to meet the peak load efficiently. Economically, the system will be feasible and more beneficial than wind Farm.

Since the system is not connected to grid, it is called standalone or off-grid system, and in that system, the storage system (such as Battery, Flywheel, Super-capacitance) need equilibrium due to fluctuation of renewable energy resource. In this case study, the system is connected to the grid, which depends on the network to supply the load that cannot be supplied by the renewable energy resource. High percentage of renewable energy connected to the grid, can affect the overall stability of the network. Moreover, some load demand considered as a critical demand in some commercial building and hospitals. As a result, even if the system connected to the grid in some cases there still need to install a storage system. The most common storage system used is the battery, more than one factor must be considered when selecting the battery. The factors include the rated capacity of the battery, depth of charge and discharge, efficiency of charge and discharge and the autonomy which present the allowed number of charge and discharge over the lifespan of battery. However, battery storage system is costly, and it considers as the most expensive equipment in the system.

\section{Conclusion}

The result showed that installing a PV solar farm have many advantages than installing wind farm. The main advantages for the PV system are that the system needs lower installed capacity $(1035 \mathrm{kw})$ than wind system $(2000 \mathrm{kw})$ to meet the same load demand, which makes the system more efficient to meet the demand, especially at peak time. Economically the PV system is much feasible than Wind, which needs lower installed capital $(£ 1.55 \mathrm{M})$ when it compared with $(£ 2 \mathrm{M})$ as the capital cost for wind system.In addition, no replacement needs for the project life. Finally, the maintenance cost of PV is $(£ 0.13 \mathrm{M})$ which is much lower than that needed for wind $(£ 1.3 \mathrm{M})$. Also, the area needed to install the PV system $\left(5.2 \mathrm{Km}^{2}\right)$ is significantly higher than that need to install wind system $\left(2.4 \mathrm{~km}^{2}\right)$. Finally, PV provide a lower renewable fraction of overall generation over the year $(65.5 \%)$ than wind $(80.8 \%)$.

The main advantages of the installed wind farm are that the wind farm needs less area to be installed than solar PV and it provides $80.8 \%$ renewable fraction of overall generation over the year. However, the wind system has a significant disadvantage such as low efficiency and less reliability, especially during the peak demand time. Wind farm choice is less feasible economically when compared to PV system, because the higher capital cost, high replacement, operating and maintenance cost is roughly ten times higher than that for PV.

\section{References}

[1] M. Al-omary, M. Kaltschmitt, and C. Becker, "Electricity system in Jordan: Status \& prospects," Renew. Sustain. Energy Rev., vol. 81, no. August 2016, pp. 2398-2409, 2018.

[2] NEPCO, "National Electric Distribution Company annual report," 2017.

[3] NEPCO, "National Electric Power Company Annual Report 2018," 2018.

[4] S. Malkawi, M. Al-Nimr, and D. Azizi, "A multi-criteria optimization analysis for Jordan's energy mix," Energy, vol. 127, no. 13, pp. 680-696, 2017.

[5] J. R. Steiner, "Energy security in Jordan (Master's thesis)," 2015.

[6] G. Holtz, “Analysing the transition of Jordan's electricity system: Underpinning Transition pathways with mechanisms," 2015, no. September.

[7] N. A. Rahim, "RENEWABLE ENERGY PROSPECTS IN JORDAN Prepared by,” no. October, pp. 1-12, 2014.

[8] J. O. Jaber, F. Elkarmi, E. Alasis, and A. Kostas, "Employment of renewable energy in Jordan: Current status, SWOT and problem analysis," Renew. Sustain. Energy Rev., vol. 49, pp. 490-499, 2015. 
[9] A. M. Baniyounes, "Renewable energy potential in Jordan," Int. J. Appl. Eng. Res., vol. 12, no. 19, pp. 83238331, 2017.

[10]Y.Anagreh and A. Bataineh, "Renewable energy potential assessment in Jordan," Renew. Sustain. Energy Rev.,vol. 15, no.5, pp. 223-2239, 2011.

[11]O. Al-Nhoud and M. Al-Smairan, "Assessment of Wind Energy Potential as a Power Generation Source in the Azraq South, Northeast Badia, Jordan,” Mod. Mech. Eng., vol. 05, no. 03, pp. 87-96, 2015.

[12]G. J. Dalton, D. A. Lockington, and T. E. Baldock, "Feasibility analysis of stand-alone renewable energy supply options for a large hotel," Renew. Energy, vol. 33, no. 7, pp. 1475-1490, 2008.

[13] Y. El-Tous, S. Al-Battat, and S. A. Hafith3, "Hybrid wind-PV grid connected power station case study: Al Tafila, Jordan,” Int. J. Energy Environ., vol. 3, no. 4, pp. 605-616, 2012.

[14]W. M. Amutha and V. Rajini, "Cost benefit and technical analysis of rural electrification alternatives in southern India using HOMER,” Renew. Sustain. Energy Rev., vol. 62, pp. 236-246, 2016.

[15]Y. El-Tous, "Grid connected PV system case study: Jiza, Jordan,” Mod. Appl. Sci., vol. 6, no. 6, pp. 92-98, 2012.

[16]E. C. Okonkwo, C. F. Okwose, and S. Abbasoglu, "Techno-economic analysis of the potential utilization of a hybrid PV-wind turbine system for commercial buildings in Jordan," Int. J. Renew. Energy Res., vol. 7, no. 2, pp. 908-914, 2017.

[17]E. Algadhi, A. Asharaa, and A. Almraid, “Comparative study for optimal re - planning of Libyan western boarder $30 \mathrm{~K}$. V system using the conventional methods and distri- bution generation penetration method," no. March, pp. 3-7, 2018.

[18] M. Halawani and C. S. Özveren, “A Hybrid Power System for remote areas in Jordan,” Proc. Univ. Power Eng. Conf., vol. 2015-Novem, 2015.

[19] S. Salehin, M. T. Ferdaous, R. M. Chowdhury, S. S. Shithi, M. S. R. B. Rofi, and M. A. Mohammed, "Assessment of renewable energy systems combining techno-economic optimization with energy scenario analysis," Energy, vol. 112, pp. 729-741, 2016.

[20]R. Srivastava and V. K. Giri, “Optimization of hybrid renewable resources using HOMER,” Int. J. Renew. Energy Res., vol. 6, no. 1, pp. 157-163, 2016.

[21]C. Zalengera, "A study into the techno-economic feasibility of photovoltaic and wind generated electricity for enhancement of sustainable livelihoods on Likoma Island in Malawi” Loughborough University, 2015.

[22]HOMER, "Hybrid Optimization Model for Electric Renewable (HOMER).” HOMER Energy LLC., USA, 2019.

[23] R. H. A. Zubo, G. Mokryani, H. Rajamani, J. Aghaei, T. Niknam, and P. Pillai, "Operation and planning of distribution networks with integration of renewable distributed generators considering uncertainties : A review," Renew. Sustain. Energy Rev., vol. 72, no. May 2016, pp. 1177-1198, 2017.

[24] Maphil, "Physical Location Map of Jordan, highlighted continent," 2020. models\&utm_medium=cpc\&utm_campaign=offers.

[25]G. Mokryani, P. Siano, and A. Piccolo, "Optimal allocation of wind turbines in microgrids by using genetic algorithm," pp. 613-619, 2013.

[26] Northernpower, "Wind Turbine datasheet," 2017.

[27]P. Siano and G. Mokryani, "Probabilistic Assessment of the Impact of Wind Energy Integration Into Distribution Networks," vol. 28, no. 4, pp. 4209-4217, 2013.

[28] Vistas, "Wind Turbine datasheet," 2018

[29]NORVENTO, "wind turbine datatsheet," 2020. [Online]. Available: https://www.norvento.com/en/for-smallcompanies/.

[30]XANTM-21, "Wind Turbine datasheet," 2017.

[31] Maehlum, "Top 10 Cheapest (Best Value) Solar Panels - Energy Informative,” 2020.

[32] AZoCleantech, "Solar (PV) Panel Comparison for Efficiency," p. 2020.

[33] Maehlum, "Which Solar Panel Type is Best Mono-Polycrystalline or Thin Film?. Energy Informative," 2020. 